\title{
Implementation of the Healthy Indonesia Card Program at the Sayang Rakyat Regional General Hospital, Makassar City
}

\author{
Syamsuddin Maldun $^{1}$, Saenab $^{1}$, Hasriani ${ }^{1}$, Imran Ismail ${ }^{1}$ \\ Corresponding Email: syamsuddinmaldun.universitasbosowa@gmail.com \\ ${ }^{1}$ University of Bosowa, Indonesia
}

\begin{abstract}
Quality health services are a hope for every Indonesian people, because this is closely related to one aspect of fulfilling basic life needs for humans, therefore it requires commitment from these health service providers, especially hospitals in supporting the implementation of government programs through the Healthy Indonesia Card. The purpose of this study is to determine and analyze the implementation of services based on the Healthy Indonesia Card program at the Sayang Rakyat Regional General Hospital in Makassar City using qualitative research methods. The results showed that the implementation of the Healthy Indonesia Card program at the Sayang Rakyat Regional General Hospital in Makassar in general was in accordance with the South Sulawesi Provincial Regulation regarding health providers and regarding cooperation in providing free health services, and presidential regulation (Perpres) Number 64 of 2020 concerning National health insurance. This is reflected in the implementation of services provided by the Sayang Rakyat Hospital to patients using the Healthy Indonesia Card (KIS) (PBI) which do not differentiate from general patients or other insurance users, provided that the patient has met the terms and conditions as a KIS patient (PBI). All medical expenses for KIS patients (PBI) who undergo outpatient or inpatient treatment are entirely borne by the government.
\end{abstract}

Keywords: Program Implementation, Service, Healthy Indonesia Card

Received: November 9, 2021

Revised: December 15, 2021

Accepted: December 31, 2021

\section{Introduction}

Health is one of the most important elements in national development. According to Momon Sudarma (in Anggraini 2014) health is a right and investment, every citizen, including the poor, requires a system that regulates the implementation of efforts to fulfill the rights of citizens to live healthy lives. The low level of public health can also be caused by the inability to obtain health services due to the high cost of services to be paid (Indonesia, 2014).

According to Sekar Komariah (2015) in Law Number 23 of 1992 concerning health, it is explained that health development is one of the national development efforts to achieve awareness, willingness and ability to live healthy for every population in order to realize optimal health degrees as one element of general welfare. in national goals. The importance of health encourages the government to establish health services (Koeswadji, 1996).

Given that a country will be able to carry out development properly if it is supported by a physically and mentally healthy community. Therefore, the government issued Law Number 40 of 2004 concerning the National Social Security System (SJSN) which regulates how the Government is obliged to provide social security to all residents in Indonesia in the form of guarantees for health care costs, old age benefits and so on. In the regulation it is emphasized that there are 5 (five) Social Security Programs including; Health Insurance, Work Accident Insurance, Old Age Security, Pension Security and Death Insurance (Astuti, 2018). 
Towards the six years of implementing the National Health Insurance (JKN) in the midst of the new government, President Jokowi issued the Healthy Indonesia Card which at first glance looks the same as the JKN program. Minister of State Secretary, Pratikno (in Luqman Hakim 2014) emphasized the launch of three Sakti Cards, namely the Smart Indonesia Card (KIP), Healthy Indonesia Card (KIS) and Prosperous Family Card (KKS) based on the Amendment to the Revised State Revenue and Expenditure Budget Law (APBNP). 2014. KIS is a continuation of the Health Social Security Administration Agency (BPJS) program which was launched on January 12014 . KIS is a complement to the government's efforts to provide welfare to the community in the health sector. KIS guarantees that health facility services do not differentiate participants based on social status (Vandawati et al., 2017).

As a form of the Free Public Health Service Program, the South Sulawesi Provincial Government built the Sayang Rakyat Hospital. Where people no longer need to think about financing when they need health services because all the financing is borne by the government. This is in accordance with the health development tagline that has been proclaimed, namely "Health is Free". Part of free health explained that patients are treated in class III Government Hospitals using generic drugs. So all the services provided by the Sayang Rakyat Hospital, both inpatient, outpatient and the cost of medicines are all free while still providing standard services (Latief et al., 2005).

After several years, it was found that the Indonesia Sehat Card service system was not completely free of charge because there were still payments for some medicines in hospitals that provided Healthy Indonesia Card services. There are several rules for service requirements that are still weak, making it possible for some people who have not been able to take advantage of these services.

The existence of patient dissatisfaction in getting health services using the Healthy Indonesia Card at the Sayang Rakyat Hospital is caused by the health service provider being less than optimal for the patient

\section{Literature Review}

\section{Public Policy Implementation}

Wahab (2012) describes that the implementation of most public policies or government programs will inevitably involve a number of policy makers, each of whom strives to influence the behavior of frontline bureaucrats/street level bureaucrats in order to provide services or services. to society, or regulate the behavior of one or more target groups.

According to the Edward III model in Ahmadi \& Widodo, (1991) proposes four factors or variables that influence the success or failure of policy implementation. These variables or factors include variables or factors of communication, resources, and bureaucratic structure as follows:

\section{Communication factor}

Communication is defined as the process of delivering communicator information to the communicant. Policy communication means the process of delivering policy information from policy makers to policy implementers.

\section{Resources}

Resources in policy implementation play an important role, because policy implementation will not be effective if the supporting sources are not available. The resources referred to are human resources, budgetary resources, equipment resources, and information and authority resources. 


\section{Bureaucratic Structure}

According to (Edward III, 2003), policy implementation may still be ineffective due to the inefficiency of the bureaucratic structure (deficiencies in the bureaucratic structure). This bureaucratic structure includes aspects such as organizational structure, division of authority, relationships between organizational units within the organization concerned, and organizational relationships with outside organizations and so on.

\section{Health Services}

Health services are dynamic activities in the form of helping to prepare, provide and process and assist the needs of others. According to Lovely and Loomba (in Muriany 2016) health services are every effort that is carried out individually or together in an organization to maintain, improve health, prevent and cure disease and restore the health of individuals, families, groups and/or communities. In addition, it can also be interpreted as health services in meeting community needs in the form of healing, prevention, treatment and restoration of body organ functions as before (Sofiana, 2020).

According to WHO (1997) health is a state of complete complete well-being including physical, mental and social well-being and not merely the absence of disease or infirmity. Meanwhile, the health system is a collection of various complex and interrelated factors that exist in a country that are needed to meet the health needs and demands of individuals, families, groups and communities when needed (Rosyadi, 2017).

In Indonesia, the definition of the National Health System (SKN) is an order that reflects the nation's efforts to increase the ability to achieve optimal health degrees as a manifestation of general welfare (Mubarak 2005). Service is a dynamic activity in the form of helping, preparing, providing, processing and assisting the needs of others (Anggara, 2012).

Based on the formulation of the definition above, it can be understood that the form and type of health services depend on several factors, namely the organization of services: health services can be carried out alone or together as members in an organization; The purpose or scope of activity: prevention of disease, maintenance and improvement of health status, healing or treatment and restoration of health; Service targets, while service targets consist of individuals, families, groups, and communities (Adrianto, 2015).

\section{The Principles of Excellent Service in the Health Sector}

Excellent service is or commonly referred to as excellent service, which is very good service or the very best service, in accordance with applicable standards, in other words, excellent service is concern for customers by providing the best service to facilitate ease of needs and realize community satisfaction (Barata, 2004). Excellent service in the health sector is the best service provided by hospital employees to meet/even exceed the expectations of hospital service users but must be in accordance with the principles of good excellent service. The principles of excellent service in the health sector are as follows (Mubarak, 2005):

Prioritizing customers, service procedures are structured for the convenience and comfort of customers, not to facilitate our own work. If our service has external and internal customers then there must be different procedures and separate funds for both. If our services also have indirect customers, we must separate the types of services that are suitable for both and prioritize indirect customers. In an effective system, the service process needs to be seen as a real system (hard system), namely an arrangement that combines the work results of various 
units within the organization. This combination must be seen as a service process that takes place in an orderly and smooth manner in the eyes of the customer.

Serving with conscience (soft system), in face-to-face transactions with customers, prioritizing the authenticity of attitudes and behavior in accordance with conscience, artificial behavior is very easily recognized by customers and worsens the personal image of service. Continuous improvement, customers basically also learn to recognize their needs from the service process. The better the quality of service, the more difficult it will be to produce customers, because the demands are also getting higher, the needs are also expanding, and diverse, so as a service provider, you must make continuous improvements. Empowering customers, offering types of services that can be used as resources or enhancements by customers to solve their daily life problems.

Refers to the level of whether or not a service is good or not, because the measure of whether or not a service is good or not is not easy to understand. because each service has its own characteristics, and is used in a different service environment. Measures of service quality are often found in various fields of study, namely; (1) The service process is carried out in accordance with standard service procedures. (2) Service officers have the necessary competencies. (3) The implementation of services is supported by adequate technology, facilities and infrastructure. (4) The service is carried out not contrary to the code of ethics. (5) Service implementation can satisfy customers. (6) The implementation of services can satisfy service officers (Mubarak, 2005)

\section{Methods}

This study uses a qualitative method, the instrument or research tool is the researcher himself. Researchers become human instruments that function to determine the focus of research, select informants as resources, collect data, assess data quality, analyze data, interpret data and draw conclusions. Researchers as instruments need to be "validated" how far they are ready to conduct research which then goes into the field (Sugiyono, 2007). This research was conducted in October-December 2020. The location of the research was carried out at the Sayang Rakyat Regional General Hospital in Makassar.

\section{Results and Discussion}

The results obtained through interviews, observations and documentation show that the implementation of the Healthy Indonesia Card-Based Service Program at the Sayang Rakyat Regional General Hospital in Makassar has been carried out properly and correctly, and has met the criteria for being effective and efficient, rational according to the needs or complaints of patients. the. This can provide an indication that the implementation of the Healthy Indonesia Card Program at the Sayang Rakyat Makassar Regional General Hospital has been carried out correctly, so in managing services or implementing the implementation of services based on the Healthy Indonesia Card program at the Sayang Rakyat Regional General Hospital Makassar for patients using the Healthy Indonesia Card. , the authors use service implementation indicators according to the Edward III model in Ahmadi \& Widodo, (1991) proposes factors that influence the success or failure of policy implementation, namely as follows: 1) Communication factors (communication), 2) Resources (Resources), 3) Bureaucratic structure (bureaucratic structure). These indicators determine the implementation of services provided by the Sayang Rakyat Hospital to patients using the Healthy Indonesia Card, both outpatients and inpatients. 


\section{Factors of Communication}

Communication is a means to make policy implementers understand what they should be doing. Every policy that will be implemented can be channeled to the right people through communication that must be stated clearly, precisely, and consistently. Clear, precise and consistent communication is expected to be effective in conveying information that can be clearly received by the implementor, target group, and other interested parties, especially with regard to the aims, objectives and targets of public services to be implemented.

Based on the interview above, medical officers and administrative officers in carrying out their duties in providing services to patients using the Healthy Indonesia Card (KIS) are quite good. From the indicators used to assess whether administrative officers and medical officers in the dissemination of the Healthy Indonesia Card to patients have been achieved.

From the results of this study, it was found that the information from the Sayang Rakyat Hospital had been patterned well and systematically so as to facilitate and accelerate the implementation of services to implement the substance of the program/policy of the Healthy Indonesia Card (KIS) program. Likewise, the informants from the community stated that the implementation of health services based on the Healthy Indonesia Card program had been well communicated and socialized to patients. Thus, the implementation of the Jamkesmas program policy from the communication dimension has been well communicated by the Sayang Rakyat Hospital.

\section{Resources}

Resources in the context of implementing services based on the Healthy Indonesia Card program at Sayang Rakyat Hospital consist of human resources, ranging from leadership to implementing employees, equipment, work facilities, financial materials and authority. Without adequate resources, it is certain that services cannot be implemented effectively. To implement the services of the Healthy Indonesia Card program, the Healthy Indonesia Card program at the Sayang Rakyat Hospital is supported by adequate and quality resources because the officers have the right health education background with functional divisions/positions at the Sayang Rakyat Hospital.

The resources that the researchers took were human resources and facilities, the results showed that at the Sayang Rakyat Makassar Hospital the administrative staff and medical staff were sufficient, while the facilities were sufficient. From the resource indicators used to assess human resources (administrative officers, medical officers) and facilities in the implementation of services to KIS patients (PBI) in serving patients, it can be said that they have met the resource indicators.

\section{Bureaucratic Structure}

Organizational structure is a formal system of relationships and tasks and authorities to control people, organizations and coordinate their actions in using resources to achieve organizational goals. Robbins (1994) suggests that organizational structure is a system of implementing tasks to be assigned, who does what and reports to whom, formal coordination mechanisms and interaction patterns to be followed. Meanwhile, Edward in Winarno (2007) said that the bureaucracy is one of the most frequent agencies, even as a whole as a policy implementer. Bureaucracy either consciously or unconsciously chooses organizational forms for collective agreement in order to solve social problems in modern life.

Medical officers and administrative officers in carrying out their duties of providing services to patients using the Healthy Indonesia Card (KIS) refer to SOPs and regional regulations and presidential regulations regarding national health insurance. 
From the indicators used to assess administrative officers and medical officers in serving patients, they follow a bureaucratic structure. Hospital Sayang Rakyat administrative officers and medical officers in serving patients follow a bureaucratic structure.

Health decentralization also makes the health sector a local government affair that must be accountable to the community. Thus health development is one measure in assessing the performance of local governments to the community.

For the service system at the Sayang Rakyat Hospital in Makassar to see in implementing the Healthy Indonesia Card program with the function of organizing health efforts that are healing and recovering for patients.

Ahmadi \& Widodo, (1991) says that communication is the process of delivering information from the communicator to the communicant. Meanwhile, policy communication is the process of delivering policy information from policy makers to policy implementers.

In this study, what researchers want to see is the process of delivering information from policy implementers to policy target groups regarding the implementation of health services based on the Healthy Indonesia Card program at Sayang Rakyat Hospital. As for the process of delivering information from policy makers to policy implementers in services, it is quite clearly stated in the South Sulawesi Provincial Regulation on Cooperation in the Implementation of Free Health Services and with Presidential Regulation (Perpres) Number 64 of 2020 concerning National Health Insurance.

Based on the results of interviews that socialization of the Healthy Indonesia Card (PBI) is not the main task of health workers if new patients use the Healthy Indonesia Card (PBI) at the Sayang Rakyat Hospital, there is an explanation and directed to follow the existing SOPs and procedures, if there are old patients who ask about The procedure at the Sayang Rakyat Hospital regarding the KIS (PBI) has only just been explained by the administrative officers and medical officers. because administrative officers and medical officers are more focused on health services. And so far, patients are considered to already know about the Healthy Indonesia Card, this is evident from the large number of Healthy Indonesia Card patients who come to the Sayang Rakyat Hospital with complete requirements to be able to obtain the Healthy Indonesia Card service.

This is in accordance with statements from interviews with patients that so far they have received information about KIS from sub-districts and health centers during the distribution of the Healthy Indonesia Card (KIS) (PBI), so that patients understand and are not confused. This proves that the socialization of the Healthy Indonesia Card (KIS) (PBI) carried out by administrative officers and medical officers at the Sayang Rakyat Hospital has been quite good.

Based on the results of this study, the information on the Healthy Indonesia Card (KIS) (PBI) program at the Sayang Rakyat Hospital was good enough by administrative officers and medical officers to patients. This means that communication in the implementation of health services based on the Healthy Indonesia Card program at the Sayang Rakyat Hospital is quite good. When it comes to the resources referred to in this research, it includes human resources and facilities in health services based on the Healthy Indonesia Card program in order to support the successful implementation of services. According to Edward III in Ahmadi \& Widodo, (1991) states that resources have an important role in service implementation.

From the results of interviews submitted by several informants said that regarding human resources including administrative officers and medical officers, for now they are quite ready to provide services to patients with the Healthy Indonesia Card, if there is an addition if there are officers who retire or administrative officers and medical officers who graduated as ASN. 
In terms of facilitation, for now, the facilitation at the Sayang Rakyat Hospital is sufficient, if there is assistance provided by the regional or central government.

Based on the results of the interview, it can be said that the resources available at the Sayang Rakyat Hospital have been able to support the Healthy Indonesia Card (KIS) (PBI) program. Meanwhile, regarding the bureaucratic structure in the Healthy Indonesia Card (KIS) (PBI) service at the Sayang Rakyat Hospital, the implementation of the Healthy Indonesia Card (KIS) (PBI) service at the Sayang Rakyat Hospital always refers to presidential regulations regarding the implementation of national health insurance and regional regulations. South Sulawesi regarding cooperation in providing free health services. From the results of the interview that the existing bureaucratic structure at the Sayang Rakyat Hospital follows the existing SOPs and procedures so that it can support the implementation of health services based on the Healthy Indonesia Card (KIS) (PBI) program.

\section{Conclusion}

The implementation of services based on the Healthy Indonesia Card program at the Sayang Rakyat Regional General Hospital in Makassar is generally in accordance with the South Sulawesi Provincial Regulation Number 7 of 2012 concerning health providers, South Sulawesi Provincial Regulation Number 9 of 2016 concerning Amendments to South Sulawesi Provincial Regulations Number 2 of 2009 concerning Cooperation in the Implementation of Free Health Services, and Presidential Regulation (Perpres) Number 64 of 2020 concerning National Health Insurance. This is reflected in the implementation of services provided by the Sayang Rakyat Hospital to patients who use the Healthy Indonesia Card (KIS) (PBI) which does not differentiate from general patients or other insurance users, provided that the patient has met the terms and conditions as a KIS patient (PBI). All medical expenses for KIS patients (PBI) who undergo outpatient or inpatient treatment are entirely borne by the government.

\section{References}

Adrianto, M. A. (2015). Pengaruh Kinerja Pegawai Dan Sistem Pelayanan Terhadap Tingkat Kualitas Pelayanan Transportasi Udara (Studi Pada Maskapai Garuda Indonesia Di Bandara Abdul Rachman Saleh, Malang). Jurnal Administrasi Publik, 3(12), 20142020.

Ahmadi, A., \& Widodo, S. (1991). Psikologi Belajar (Jakarta: Rineka Cipta). Arikunto, Suharsimi.(1993). Prosedur Penelitian. Jakarta: Rineka Cipta.

Anggara, S. (2012). Ilmu Administrasi Negara: Kajian Konsep, Teori, dan Fakta Dalam Upaya Menciptakan Good Governance (Vol. 1). CV Pustaka Setia.

Astuti, P. (2018). Analisis Undang-Undang No. 40 Tahun 2004 Tentang Sistem Jaminan Sosial Nasional Ditinjau Dari Konsep Jaminan Sosial Kesehatan Rakyat Dalam Hukum Islam (Doctoral dissertation, IAIN Purwokerto).

Barata, A. A. (2003). Dasar-dasar pelayanan prima. Elex Media Komputindo.

Edward III, G. C. (1980). Implementing public policy. Congressional Quarterly Press.

Indonesia. (2014). Undang-Undang Nomor 24 Tahun 2011 tentang Badan Penyelenggara Jaminan Sosial. Kementerian Tenaga Kerja dan Transmigrasi, Republik Indonesia.

Koeswadji, H. H. (1996). Undang-Undang nomor 23 tahun 1992 Tentang Kesehatan: asasasas dan permasalahan dalam implementasinya. Citra Aditya Bakti.

Komariah, S. (2015). Perencanaan komunikasi Badan Penyelenggara Jaminan Sosial (BPJS) Kota Balikpapan dalam mensosialisasikan Program Jaminan Kesehatan Nasional 
(JKN) kepada masyarakat Kota Balikpapan. Ejournal Ilmu Komunikasi, 3(2), 107121.

Latief, R., Kadir, A. R., \& Nur, N. B. (2005). Kualitas Pelayanan Dan Kepuasan Pasien Rawat Jalan Di Rumah Sakit Umum Daerah Labuang Baji Makassar: Pendekatan Analisis Voice of Costumer (VOC). Jurnal analisis Pemasaran, 13-20.

Mubarak, W. I. (2005). Pengantar Keperawatan Komunitas 1. repo.unikadelasalle.ac.id

Robbins, S. P. (1994). Teori Organisasi Struktur, Desain \& Aplikasi. Jakarta: Arcan.

Rosyadi, F. (2017). Kualitas Pelayanan Badan Penyelenggara Jaminan Sosial (Bpjs) Kesehatan Di Puskesmas Wonoayu Kabupaten Sidoarjo. Jpap: Jurnal Penelitian Administrasi Publik, 3(1).

Sofiana, M., Wahyuni, R., \& Supriyadi, E. (2020). Studi Komparasi Kepuasan Pasien BPJS Dan Non BPJS Pada Mutu Pelayanan Pendaftaran Puskesmas Johar Baru Jakarta Pusat. Abiwara: Jurnal Vokasi Administrasi Bisnis, 1(2), 93-110.

Vandawati, Z., Sabrie, H. Y., Pawestri, W. D., \& Amalia, R. (2016). Aspek Hukum Kartu Indonesia Sehat. Yuridika, 31(3), 498-520.

Wahab, S. A. (2021). Analisis kebijakan: dari formulasi ke penyusunan model-model implementasi kebijakan publik. Bumi Aksara.

Winarno, B. (2007). Kebijakan publik: Teori dan proses. Yogyakarta: Media Pressindo. 